Sign Systems Studies 49(3/4), 2021, 400-417

\title{
Semiotics of the pornographic face: From traditional porno to Beautiful Agony
}

\author{
Bruno Surace ${ }^{1}$
}

\begin{abstract}
Today's pornography constitutes a semiotic laboratory capable of meticulously describing some characteristics of the cultures from which it comes and for which it is intended. In it, the role of the face is preeminent and assumes relevance both from a diegetic and a formal point of view. A face which makes itself a sign and is articulated in a dialectic between the syntagmatic and the paradigmatic axis, finding expression as an aspectual device, establishing a peculiar semiotic procedure of absentia in praesentia, and highlighting an eminently enunciative dimension of the textual genre. Thus a facial semiotics of pornography becomes to all effects a cultural semiotics, which through the exploration of a transversal genre - both in its mainstream and more niche actualizations - produces significant results in defining how cultures of the face, including extrapornographic ones, delineate themselves. The aim of this article is to verify this peculiar facial semiotics through a case history that stretches from traditional to contemporary pornography, also analysing the "facial pornography" website beautifulagony.com and the visual works of some contemporary artists.
\end{abstract}

Keywords: semiotics of pornography; pornographic faces; erotic faces; face studies; semiotics of the face

\section{Introduction}

There is a branch of contemporary pornography in which the censorship of the face is frequent through a peculiar "veil system" (Leone, de Riedmatten, Stochita 2016) effectuated with various techniques (pixellation, face off, masks, etc.). However, it is undeniable that the face plays a fundamental role in a large part of (both early and current) mainstream pornography, performing various functions.

First of all, it is a sort of ontological and phenomenological guarantee, which in a sense certifies the humanity of the body dissected by the shots. The mechanical nature of the pornographic sexual act, in fact, based on a standardized repetition

1 Department of Philosophy and Education Science, University of Turin (Unito), Turin, Italy; e-mail address: b.surace@unito.it. 
compulsion, requires the face of the actors as proof that they really exist, that they are situated entities which are watching as well as being watched. ${ }^{2}$ This proof is provided by the editing, through a well-codified grammar, which expertly indulges on the faces of the actors, female and male, interspersing face shots with those of other parts of the body to decrease the degree of impersonality and recompose the fragmented body, also germinating a series of genre variations ranging from facial, to gonzo point of view, to sub-genres such as that of 'eye contact' (basically an 'uninterrupted interpellation').

Thus, we connect to the second function of the face: when present, it is de facto the actualization of the emotional side of pornography. Porn faces are, in terms of tensive semiotics, constantly contracted figures $d u$ corps (Fontanille 2004). Prosthetic in their muscularity, exaggeratedly joyful or on the edge of suffering, porn faces are semantically revealed in their enjoyment, in that "beautiful agony" which lends its name to a "historical" viral site (beautifulagony.com), in which the porn is paradoxically founded on the censorship not of the face, but of the rest of the body. Its homepage contains a mosaic of thousands of faces in close-up, continuously posted by users from 2004 to the present day, captured in the act of "la petite mort" (as the site claims). The videos depict its various phases (preparation, achievement, completion, exhaustion), while the thumbnails crystallize its lasting aspectuality, eternally experienced in the facial contraction that sanctions the "facial climax". It is the aspectuality of the orgasmic face as mandatory proof of the authenticity of the pornographic content on which an aesthetic universe hinges that makes the face, "naked and singular" (Lévinas 1984; Ponzio 2007), the true fulcrum of the textual genre. Its power transcends the genre as poster art in films such as Lars von Trier's Nymphomaniac (2013), but also in the black and white photographs of Lithuanian Albert Pocej, in Argentinian Diego Beyro's Orgasms series, and in the series that cover the entire range of orgasmic aspectualities (inchoative, lasting, terminative) in Brazilian Marcos Alberti’s O Project. ${ }^{4}$

2 In this sense we can undoubtedly identify parallels with the phenomenology of Deleuzian, Merleau-Pontyian, and more recently Žižekian derivation. As regards Žižek, given the vastness of his work, we will only mention the 1996 work coedited with Renata Salecl (Salecl, Žižek 1996), the 2004 text dedicated to Deleuze (Žižek 2004a) and the text of the same year on the gaze, edited in the Italian version by Damiano Cantone and Lorenzo Chiesa (Žižek 2004b) as particularly suitable for those wishing to approach this article or the phenomenological philosophy of the Slovenian scholar. As for the closer relationship between semiotics and psychology, the fundamental reference, which also imbues the pages of this essay, is Barthes 1973.

3 Already called so by Elisabeth Lloyd (2005), who studied the expressions of stumptail macaques in the wake of Suzanne Chevalier-Skolnikoff.

4 A semiotic reflection on the orgasmic body in traditional porn cinema can already be found in da Silva 2013. 
It is, in other words, a real face-based "cultural epidemiology", which in the web era mutates in content as in the video $O$ Face, produced by DirtyFit and with over three million views on YouTube, in which the aesthetics of beautifulagony.com is transliterated from the rhetoric of amateurs to a professional production, or in the series of viral videos Hysterical Literature made by the American photographer Clayton Cubitt, where women filmed in the medium field in black and white read famous poems while a vibrator is in action between their legs. The emphasis in all the cases mentioned is always on the face as an ante litteram immersive device, the unknown protagonist of pornography because of its semiotic power of empathic production - if it is true that watching porn corresponds to an "entanglement of somatic and semiotic intensities" (Voros 2014: 249) ${ }^{5}$ - which, on the one hand, causes reflection of a semiotic and even anthropological nature ${ }^{6}$ and, on the other, certainly pushes us to interrogate modern neuroscience. ${ }^{7}$ If you think about it, tout se tient: while watching a film you cry not at the moment of the tragedy, but at the moment in which you see the desperation on the faces of those who are living it inside the narration.

\section{The face in porn from the syntagmatic to the paradigmatic axis 8}

The face in the erotic and pornographic context can be understood as a sign, whose position in the semiosphere is not fixed, but stretched between the peripheries and the centre, by virtue of epochs, genres, geographical locations, gender of the protagonists, that is, within a broad cultural spectrum. In the porn "of yesteryear", for example, it occupies a syntagmatic, rather than paradigmatic, role. An absence of the face is not substantially envisaged. It is implicated as a sign in the specific construction of the pornographic text, and de facto constitutes an aspectual marker that pre-determines the transition from the durative to the terminative phase. In narrative terms, the close-up focusing on the face of the male actor is a sine qua non for the staging of the "cumshot", which, as already claimed by Ortoleva (2009: 318), constitutes the pivotal moment of heterosexual pornographic textuality, meaning pornography "as a 'regime of representation, a

\footnotetext{
$5 \quad$ Voros in turn refers to Paasonen 2007.

6 Think of the ethnographic study of the joyful face by Chen et al. 2018, or Fernández-Dols, Carrera and Crivelli's 2011 study on facial behaviour while experiencing sexual excitement.

7 Cf. Gallese, Guerra 2015; D’Aloia, Eugeni 2017.

8 The sense in which we will use the notions of the syntagmatic and the paradigmatic axes is that traditionally shared by semiotics, which refers to Saussure 1916.
} 
genre assembled out of certain combinations of camera angles and lighting, bodily postures, apparel, footwear, and the like" (Longhurst et al 2017: 306) ${ }^{9}$. The role of the face is here inevitable, and provides the basis for a theoretical reflection that goes beyond the context of hardcore. In fact, if on a cultural level the male orgasm is given as authentic by definition, as not simulable (and therefore as an act whose semioticity is doubtful $)^{10}$, it is clear that the emotional-bodily imprint of the face is essential to trigger engagement which otherwise, if relegated to the exclusive profilmic emphasis on the genitals, would be less meaningful. Or at least it is so in the pornography of the 1970s and 1980s, where the female face is equally important, not only as a place where usually the reverse shot of the male face is carried out in the final scene (so frequently that it ends up constituting not just a stylistic feature, but a specific sub-genre, known as 'facial', which overflows with compilations in the porn-tubes). The woman's face, at least in mainstream heterosexual pornography, is in turn the counterpart to the male face. Its task is to signify enjoyment, which is expressed in specific muscular patterns, rotational movements of the pupils, and in general an inventory of facial figures which are the synecdoche of total relaxation, of an aesthetic of abandonment.

The role of the face in contemporary pornography is very different. To all intents and purposes there still exist "old-fashioned" films, where the syntagmatics of the montage implies specific moments when the face is central, which is counterintuitive if one thinks of it as the only human surface apparently not of pornographic significance, being an element that is not socially reprehensible (as are the genitals in most human cultures). While the genitals are usually covered at least by underwear, the face is instead the part of the body that is almost always visible. However, the production of films in which the face is completely non-existent is a dominant trend in contemporary pornography, in a strange semiotic inversion: what is usually hidden (the private parts) is emphasized, and what is usually visible (the face) is hidden. This new trend, which undermines professional pornography and sanctions the ineluctable advance of amateur or "fake amateur" porn, is in fact all enacted on an enhancement of anonymity, ${ }^{11}$ which coincides with a culture that translates porn from a media experience that everyone can enjoy into a factual experience that everyone can practise. It is legitimized porn par excellence, potentially practicable even by the author who is writing these lines, in the total protection of a face that is constantly off screen, or censored through analogue (varied and possible masking)

9 There is also a deepening of a philosemiotic approach in this sense in Kaite 1995.

10 It should, however, be noted that today this notion is more of an urban legend than anything else, because in the pornographic industry there are numerous tricks to simulate male orgasm, as already shown, for example, in Ziplow 1977.

11 A first analysis of anonymity as a semiotic strategy of occultation can be found in Leone 2018. 
or digital (pixellation, blur effects and so on) cosmetic techniques. In erotic culture the face thus assumes no longer a syntagmatic but a paradigmatic role: it can exist or, as most often happens, not exist. However, and this is the relevant element, the anonymity of this face is not only an individual protection strategy, but also an operation with a significant symbolic charge.

If we take, for example, one of the thousands of semi-professional channels on Pornhub (the principal mainstream porn-tube in the world), called 'Nyna Ferragni' from the stage name of the Italian actress who animates it, ${ }^{12}$ we notice from the thumbnails how the semiotic logic of face management configures a relevant dynamic of absentia in praesentia. The woman's body is clearly the central protagonist (as the name of the channel indicates), although there are in fact almost always two bodies that can be seen in alternation, hers and that of her partner. In fact, it is a typical trend nowadays to open channels for couples, in which people who are partners in real life re-propose their sexuality online, significantly heightening the aura of authenticity around the sexual performance represented. Usually, however, in profilmic terms these movies still identify the female character as protagonist and the male as co-protagonist, a sort of prop, biologically necessary but narratively secondary. ${ }^{13}$ So Nyna Ferragni is present in all the previews of the videos, while her male co-star appears, to an exclusively genital extent, only in some of them. His face is not visible, and is hidden for framing reasons (he is behind the camera, which he holds in his hand in full gonzo style, or is otherwise "sacrificed" to make room for her body). Instead, she is the protagonist, but her face is not seen, and its presence is averted in the most imaginative ways: she may be off screen, and therefore only her body is visible while her face is cut off by the edges of the frame; she is wearing a hat and her long hair covers a major part of her face; her face is censored by pixels; or she conceals her face with an arm, a pillow and so on. It might not always be completely occulted: sometimes the lower portion is visible, from the mouth to a piece of the nose; but you will certainly never see her eyes. In short, there is an extremely coherent dialectic between the visible and the invisible, which reifies the shift of the classic idea of "see-through". ${ }^{14}$ Everything

12 At the time of writing these lines, in December 2020, the metadata of the profile refer to 181 million views of the videos it contains, 259 thousand subscribers, and position 41 in the internal ranking of the site, which in fact is a highly relevant position considering that the site embraces thousands and thousands of internal channels.

13 It should be noted that these considerations relate exclusively to heterosexual mainstream pornography.

14 This discourse can obviously be part of a wider debate on online lifestyles as dynamics in which peculiar relationships between opacity and transparency are implemented from an identity point of view. See Thibault 2016. 
else about Nyna Ferragni is absolutely visible, exposed, overexposed; the face, on the other hand, is always veiled, rarefied, impenetrable. If in traditional eroticism everything hinges on the dialectic between concealment and modest revelation of the forms of the body, here, instead, the absent present is the face, catalyst of the attention of a new spectatorship whose sense of excitement is built around an identity which has been halved, and which therefore through interpretative cooperation is partially filled with a new order of desire.

If in earlier times the porn actress/actor was clearly identifiable as such, and resided in a specific and symbolically inaccessible hyperuranion (so much so that many films were based on the idea of "casting" in which ordinary people could engage in sexual intercourse with these clearly recognizable stars), ${ }^{15}$ today, however, s/he could be anyone, and so we fall within the paradigm of the "pornification of everyday life", which finds one of its maximum elements in the new culture of the pornographic face, together with the predominance of amateurism, the explosion of porn in public, and certainly also the burgeoning industry of live porn through webcam. ${ }^{16}$ Therefore, if the contemporary face becomes rarefied in pornography, it is legitimate to ask whether it has also abandoned its relevance. In reality, as we are discovering, the opposite is true. The hidden face is a face that exists precisely as absent or semi-present. Moreover, this was already true in early porn. When the hidden face was not yet a defined filmic object, an aesthetic of the absent face was already taking shape, as all pornography - first photographic, and in the era of deepfake also in motion ${ }^{17}$ - was based on photomontage. This operation is nothing more than the replacement of one face with another, that is, the affixing of a face on a body that does not belong to it, thus coinciding with the passage from a virtuality (the particular famous person who is considered sexy, whom you would like to see naked in the act of a sexual performance) to an actuality (the realization of the fantasy through the manipulation of images of faces forcibly displaced from their body or belonging to a different one that satisfies the perceived aesthetic needs):

15 Many successful pornographic series are born from this narrative pretext, from the historical castings of the Italian actress Eva Henger (A letto con Eva), who "auditioned" amateurs who were not particularly handsome and had no script, so as to give the viewer the idea that even s/he could enjoy that experience, up to more contemporary formats like Mea Melone CHALLENGE!, Fuck a Fan and many others.

16 The shift from the production of content designed to be deferred to that of content designed to be streamed live online is a rapidly growing fact, which has seen a boost during the pandemic period. Pornography has not been exempt from this increase in interest in live content, as evidenced by the increment in users on sites like OnlyFans. Cf. Lykousas, Casino. Patsakis 2020.

17 An analysis on deepfake with a semiotic approach appears in McCosker and Wilken 2020. 
Even before the look-alike video, the net overflows with evident photomontages where the face of a determined personage is mounted onto the body of some anonymous porn star, intent on performing the most varied pornographic acts. [...] On the part of the broadcaster, the creation of pornographic photomontages with stars as protagonists may be based on two end-goals: 1. Recreational: the broadcaster elaborates the fake for the sole purpose of introducing it onto the Web to trigger trolling activities or because he considers it an exhilarating way of mocking the unwary. 2. Lucrative: the broadcaster elaborates the fake from a desire to benefit from it in terms of visits to a particular web video (clickbaiting), the purchase of products, subscriptions and the like. Whatever the broadcaster's motivation, the focus of our interest are the users. Excluding the community of "recreational users," who recognize the fake and enjoy themselves making it circulate as such, there is certainly a slice of users who utilize these images because they find them arousing. The interesting fact is that these images appear for the most part manifestly fake. They consist either of photomontages recounting highly improbable narrative situations (a famous actress in the middle of an orgy who smiles dazzlingly at the camera) or very poorly-finished productions (where the viewer can note a difference in color between face and body, a lack of proportion and so on). (Surace 2019: 248)

Thus, the pornographic face allows us, above all, to undermine the idea of the face as an excessively biological or natural device. While there is certainly a naturalistic foundation in the movements and expressions of the face, which is difficult to falsify, it is also true that the cultures of porn transform the face into a semiotic device that acts on various layers. The first is a presential layer: the face is or is not there, and its presence in the absence or vice versa is a semiotic fact; the second is an actorial layer: the pornographic face, in the act, recites and is actorialized in Greimasian terms, that is, it has semantic properties that articulate value and aspectual dimensions, contributing to the development of a narrative that the user converts patemic-bodily onto themselves (even seeking out and concentrating on some salient moments and avoiding others, since for all intents and purposes a porn film is almost never watched in its entirety); ${ }^{18}$ the third is the layer of the post-produced face, which makes pornographic faces the places where the hidden

18 The principal mainstream pornographic sites are increasingly built around categorizations and metadata, not only designed to direct users to the videos they might like most, but even manipulating the videos themselves with various types of infographic tags, such as signs in the playback bar that indicate different "scene types" (that is, the types of position in the narrative grammar of pornographic performance), or even the histogram index of the attention curve on a single video (so that the user will directly select the most viewed parts, rather than others). Pornhub itself releases a complex report every year with many data, capable of closely tracing user profiles: https://www.pornhub.com/insights/2019-year-in-review (last consulted on 14 December 2020). 
desires of the cultures to which they refer are most fulfilled, often dichotomously (hyper-made-up faces vs "girl-next-door" faces, adult faces and therefore with wrinkles in sight (MILF) vs innocent faces (teen), angelic faces vs aggressive faces, and, again, an emphasis on the colour of hair, eyes, skin, etc). The face is therefore configured as a completely culturalized semiotic and phenomenological device. In this way, pornography allows us to verify the culturality of the face as claimed by Broekman (2011: 24-25): "1. Human faces are not a natural fact but should be understood as a cultural value; 2 . A human face is in semiotic perspective a body part that shares its artifice-character with the other parts of the body; 3 . The artifice-character plays a key role in the semiotic and legal need for name-giving; 4. Faces are thus faces in an age of semiotics". In porn, consequently, the face is rendered as a mask, and pornography as an effective laboratory in which to explore desire as a socially shared, potentially divisive, politically relevant construct. If this were not the case, then the role of the face in porn would not change, and the pornography of the past would be similar to that of the present.

\section{Aspectuality of pornographic faces}

If we have so far highlighted how the face is not a contour element in pornographic cultures, but a real dominant element, we now focus on those erotic textualities where the centrality of the face is not only functional to the development of the "arousal arc", but proudly disclosed. The most relevant case is the aforementioned website Beautiful Agony, whose subtitle is "Facettes de la petite mort". Founded in 2004, still active (which already demonstrates its success), and managed by Feck Pty Ltd in Melbourne, the site presents itself with a template à la old-fashioned hypertext, with a slender menu on the left and a central gallery in constant update of numbered videos shared by users, called Agonees. ${ }^{19}$ The visual formatting of the videos follows a specific protocol, strictly supervised by the moderators (who, moreover, have the right to delete videos in which the simulation is too evident). The thumbnails are again proof of visual expectancy: in a close-up from the shoulders up, men or women are portrayed at the moment of maximum enjoyment.

As Dean MacCannell (1989: 155) states in Faking It: Comment on Face-Work in Pornography, in sexuality "the dominant mode of communication is via facial expression, gesture, and pre-linguistic vocalization". If this is true both in everyday sexuality and in pornography, there is a rather large facial difference between the two:

19 Reflections in part similar to those we will conduct on this site can be found in Schaschek 2014, who, however, defines the site as "quasi-pornographic", while we are in all respects convinced of its full "pornness". 
The pattern of opposition between pornographic and everyday interaction also appears in "face-work". Emotional extremes in ordinary a-sexual interaction are usually signified by upper/lower face agreement or complementarity. For example, excited joy-tending-toward-rapture in the framework of everyday interaction is expressed by relaxed wide eyes and open mouth. Extremes of disappointment are expressed by a facial "crunch", the mouth and eyes close tightly and are pulled toward the center of the face. In each case, there is a muscular agreement between upper and lower, and left and right face. Expressions of emotional extremes in the pornographic frame often involve upper and lower face muscular antagonism. The eyes are open wide but the mouth is closed; sometimes the teeth are employed to keep the mouth closed. Pornographic ecstasy is expressed by the opposite form of opposition: the eyes are closed and the mouth is slack open. It is semantically similar to a-sexual expression of pain. The difference seems to be that ecstatic pornographic expression does not involve tight closure of the eyes or knitting of the brows; the eyelids are merely dropped, and the forehead remains smooth. The expression that suggests the actual experience of pain is inevitably accompanied by a heavily knotted brow and tight wincing of the eyes. The pornographic frame is often the site of spectacular whole-face muscular antagonisms that are not found in other areas of life. (MacCannell 1989: 159)

Thus the faces on Beautiful Agony are real porn, to the extent that the muscular oppositions between the top and the bottom of the face, which translate into tensive dyscrasias (one hypertensive band, the other extended), are typical of that exaltation of expressivity which, for example, in softcore or classic eroticism (that, according to an ancient dichotomy, would constitute the aesthetically worthy representation of the erotic as opposed to the alleged brutal obscenity of pornography) is instead supplanted by mono-expressiveness, an "expressionless state" (MacCannell 1989: 170). The face in the Australian site is also extreme, above all because it supplants the nudity that common sense usually associates with the term. The small portion of the body visible to us in the images and videos is often clothed at least in underwear, if not completely. What is naked is the face, abandoned to ecstasy and so magnified in its singularity. A singularity, moreover, in which perhaps the glimmer of the truth lies, if it is true that the voice can lie, and that "the first mirror is the smiling face of an observer, signifying a semiotic process" (Makolkin 2015: 574). In addition, it would seem that in fact the falsification of jouissance is actually easier vocally than facially:

A recent experiment studied the sounds women make during sex with their male partners. It turns out that these sounds have nothing to do with whether the woman is having an orgasm. The timing, frequency, and intensity of the sounds were a response to the women's male partners, and were interpreted quite reasonably by the researchers as a way of encouraging the men to "hurry up and 
finish." One, uncharitable way of interpreting such behavior, then, is a form of deception: a "fake orgasm." But that would be too harsh. It is really more like Pavlov's dinner bell, only that there is no intention of depriving the dog of his dinner. (Yelle 2013: 58) ${ }^{20}$

Beautiful Agony thus deactivates the strong categorization of desire of mainstream porn, sold according to packet switching methods that take place in the cornucopia of labels of mainstream porn sites, where a semantic indicator is associated with every possible micro-characteristic (characters, scenes, and so on). The centrality of the face as a transcultural erotic device is in fact such as to reduce categorization to a minimum choice, based on gender (Females, Males, Trans/Non Binary) and on three further subgenres (Friends, Confessions, Revival) on which we will not focus here.

There are two points worth expanding on. The first is the central role of the visual representation of orgasm through the face. Again, the pornographic context is useful for drawing general philosophical and semiotic conclusions. The success of this site is indeed empirical proof of Emmanuel Levinas' definition, which otherwise risks remaining somewhat vague and unclear, of the face as a naked and singular device (so singular that, except for a small minority, the videos on the website are almost always of a single protagonist, usually intent on the masturbatory act). What does Levinas actually mean? Our interpretation is that he is talking about a threshold device, in which the clash between semiotic and non-semiotic, that is, between natural and cultural, occurs. ${ }^{21}$ It is the idea of the orgasm as a moment of abandonment, a "petite mort", a paradoxical expression that minimizes an otherwise absolute and incontrovertible moment - death by regimenting it in a transitory dimension that is otherwise excluded (you do not usually die only for a while, except maybe in cases of people who report near-death experiences). And this peculiar moment occurs vividly rather than linguistically; it is not communicated by diegesis, but by mimesis. So the faces

20 In reality, there are also some doubts about the face, especially regarding studies on the socalled "climax face", detailed in Lloyd 2005.

21 It is worth pointing out here that the theme of the presumed distinction between natural and artificial signs, between the semiotic and non-semiotic world, is still the subject of debate today, and indeed assumes renewed importance with the increasingly relevant dialogue with disciplines of more recent formulation (such as neuroscience). The identification of a "lower threshold of semiotics", as it is designated in Eco 1975, is a complex problem that we have no intention of addressing here. Our interpretation of Levinas in these terms is therefore to be understood not from the standpoint of whoever emits the sign, but from that of the effect of meaning on whoever receives it, experiencing a sensation of "naturalness" as opposed to a previous "artificiality". 
on Beautiful Agony seem to emit meaning involuntarily, and this is constituted as such when it is traced by the user of the website, who is in turn automatically aware of this non-intentionality (whether it is simulated or not), which is the core of the experienced excitement. That is, these faces are signs that stand for nothing else - aliquid pro nihilo - placed in a median phase in which the loss of control (simulated or not, this is not the point) causes muscular and ocular reactions. These reactions are not fully "supervised". More than surveillance of the self, the faces from Beautiful Agony are in a state of souveillance, ${ }^{22}$ in the lower threshold of semiotics. The abandonment of significance in semiotic terms is not the embracing of insignificance, ${ }^{23}$ and perhaps it is not even appropriate to read a transcendent device in the face. Everything is played out on a specific, textual immanence level, within the frame. However, the face takes on meaning as the ultimate device, whose subversive charge - a linguistic subversion that repudiates embarrassment and repression ${ }^{24}$ - is the isotopy of Beautiful Agony, which shows us faces as they should not be seen culturally. In some ways they are a visual profanity.

The second important point is represented by the Trans/Non Binary category. The immediately significant data are the faces that we find within this category. In fact, if we dwell on them, we very rarely identify faces which are visually Trans/ Non Binary (for example, faces with masculine features but made up in such a way that the common imagination tends to associate them with female faces). In most cases, indeed, these faces appear to us as sexually unambiguous. Now, of course, the reason for the existence of this category therefore appears more relevant in terms of identity, rather than visuality. Trans/Non Binary users of the site, in fact (as well as other users interested in the category), presumably already have the possibility of satisfying their sexual appetites in the Males and Females categories from a visual point of view, according to their preferences. The correspondence or not between gender and biological sex is not necessarily traceable on the face. Furthermore, trans-sexuality in pornography is a genital fact, and in Beautiful Agony the genitals are taboo.

Three consequences follow: the first is that the face is something that is given visually, but in reality contains in a nutshell a substratum of axiological-ideological, and therefore semiotic, components that go beyond its visualness; the second is that the face as a synecdoche of the body in pornography presupposes a physicality,

22 We do not use this term here in the sense that is attributed to it in the debate on the contemporary panopticon from Mann 1998 (later consolidated in Mann 2004) onwards, but as a term to describe a state of reduction of self-consciousness until reaching an $a$ - or pre-semiotic condition.

23 And in fact, even the most recent semiotic studies are starting to question insignificance, as is demonstrated by Leone 2019 .

24 On the re-semantization of repression as a semio-political act, see Surace 2019. 
so that it is in fact taken for granted that in a "straight" porn film a female face corresponds to female genitals, but this is not the case for a face categorized as Trans/ Non Binary, about which a regime of doubt remains (both male and female genitals could correspond to a male or female face); the third is that the face claims, as an increasingly transcultural device, the overcoming of an archaic binarism which, although today beginning to disclose sparse visual manifestations (usually through status symbols like rock stars or influencers who make themselves up specifically to achieve an imaginary "gender fluidity" and disrupt the traditional visual dichotomy of genders), is already assimilated on the level in which the face is mediated as a discursive device, and therefore categorized. It is the distinction between seen face and said face, which causes this category to exist in Beautiful Agony, meaning that transsexuality does not necessarily pass through the face, but proudly finds its confirmation in the face. In fact, therefore, those who prefer, for example, videos \#4065 or \#4643, included in the Trans/Non Binary category but which from the preview seem to depict people who could be included in the Females category, will see in these the face of a non-binary sexuality. Behind the visual appearance of the faces there is always a political, semiotic, identitary instance.

However, Beautiful Agony is not the only place where the pornography of the face reaches its peak. If the face already plays a radical role in mainstream pornography, here this is further consolidated in some specific sub-genres such as gonzo, where the subjective point of view is magnified by the actors' faces in the foreground, and the frequent indulging in eye contact (what, in cinematographic terms, is called interpellation). Yet the power of the face as an erotic device had already been investigated in earlier times, when certain themes were still a socially shared taboo, and all the specifics we are talking about had not even been codified, if we take the 1970s as a moment of diffusion in the West of audiovisual pornography derived from magazines.

In 1964 Andy Warhol made a silent, black-and-white medium-length film entitled Blow Job. Warhol's film could to all intents and purposes be understood as a text in which a fellatio is shown and therefore, in fact, as a pornographic film. In reality, however, the history of modern pornographic cinema (excluding the experiments of early cinema) usually traces the genre's first film to the slightly later Deep Throat (Gerard Damiano 1972), although other films with simulated sexual acts, without real penetration, had been shot previously. Why is Warhol's film not mentioned? Because, in the artist's typical playful style, it betrays the expectations raised by the title. The entire duration of the film is in fact a fixed sequence closeup of DeVeren Bookwalter (uncredited), wearing a jacket with a high collar, who squirms with delight for several minutes, now grinding his mouth, now raising his face and eyes skywards, now touching his hair and, finally, after appearing to pull 
up his pants, lifting a cigarette to his lips. It is to all intents and purposes a film in Beautiful Agony style, ante litteram. The operation is clearly provocative, and plays on the way in which the title topicalizes the long shot. In fact, on the isotopic level, at least until the moment of lighting the cigarette (which has a precise cultural correspondence with the post-coital moment), the visual text does not necessarily suggest a fellatio. The actor's face is illuminated by a strong light, which often overshadows his eyes, generating dark eye sockets through a play of chiaroscuro. His movements are sometimes convulsive and sometimes more relaxed. The mouth often showily quivers:

The brief, fleeting, and erratic moments of this failure in the face work of Blow Job's poser are located at the points where his face does, in fact, appear to index unambiguous sexual pleasure via certain "genuine," that is, nonstrategic facial contortions. Correlatively, in the face work of porn performers, the failure to screen the trauma can be located in those moments that indicate the subject's momentary loss of control over his or her own strategic signification [...]. This failure can take two forms: First, it may be registered as an expression that becomes briefly yet unambiguously identified as "phoniness," and, second, taking the same effect as with Blow Job's poser's failure, it may be registered in an expression of genuine (nonprofessional) sexual pleasure. (Grundmann 2003: 36)

This consideration ultimately demonstrates a certain visionarity on the part of Warhol, who had at the same time foreseen the role of the face in contemporary porn, but also somehow the kitsch substratum that would make the first "official" pornographic films famous a few years later.

\section{Artistic and enunciative cultures of the "O Face"}

These theoretical reflections based on the face spring from the pornographic context in such a vigorous way that they are also intercepted by the production of artistic speeches and texts. A first important case is that of Albert Pocej, who decided to immortalize with photographic shots, and sometimes with time-lapse, 15 women in the moment of orgasm, producing a series of images as a sort of photographic exploration. ${ }^{25}$ The face is again central, crystallized in different poses. It is, however, no longer a foreground face. From a plastic point of view, the images are in black-and-white, as was Warhol's film - halfway, in fact, between

25 The series can be viewed at the following link: https://www.boredpanda.com/femaleorgasms-photography-albert-pocej/?utm_source=ro.pinterest\&utm_medium=referral\&utm_ campaign=organic (last accessed on 14 December 2020). 
artistic and pornographic performance (first of all a "discursive pornography", as we have established). The black-and-white photography emphasizes the whimsical character of the operation, giving it an aura of artistry, as if to signify a discourse of a certain caliber. In topological terms, nevertheless, the faces are this time in direct relationship with a background, which takes on a meaning, sometimes equal (on the eidetic level the surface covered is quantitatively the same, half and half), sometimes superordinate, as in the photograph in which the face of the woman portrayed is at the bottom right, dominated by the background of some numbered tree trunks, or in the shot where the woman has an orgasm against the backdrop of a wind turbine. Particularly significant in this sort of laparoscopy of the female orgasmic face is the photograph in which the dark background is abruptly interrupted by a beam of light which, from above, almost divinely, strikes only and exclusively the small face of the woman portrayed in her moment of ecstasy ${ }^{26}$. There is thus no close-up in a technical sense, but the lighting arrangement generates a conceptual close-up: the face in the moment of abandonment lights up; everything else for a moment - the very instant of the shot - loses its meaning, and in fact the background is black, almost unrecognizable.

Another case along the same lines is that of Diego Beyrós Orgasms series, in which a peculiar aesthetic of the surface intervenes. ${ }^{27}$ Here the face returns to the foreground, but instead of photographs, we are dealing with oil paintings on bedsheets, $210 \times 130 \mathrm{~cm}$ in size, which by their conformation lend themselves to being spread and waved, thus giving a certain airiness to the content represented, fixed on the sheet, but at the same time mobile in the air. It is also relevant that if before the face was first and foremost an index sign, photography being the physical trace of an event that took place, here we move into the sphere of iconism, mixed with the surface of the sheets which with their individual patterns (floral and geometric motifs of different workmanship), and with the paradigm of iridescent ripples according to where they are affixed, constantly re-signify these faces as paradoxical expressions of la petite mort, always the same but also constantly different. In the same vein, we can mention the work of Marcos Alberti, who with his The O Project proposes a series of images that, starting from a neutral face in the upper left corner, photographically recount the achievement of ecstasy through a visual narrative of four foreground images, against a neutral background and articulating a grammar of passion that is expressed in a dialectic between tension and relaxation, both interior - the face that changes expression - and exterior -

26 On the role of the face in ecstasy, not only sexually, but in the broadest meaning of the term, cf. Surace 2018.

27 The series can be viewed at the following link: http://www.diegobeyro.com/orgasm-series\#1 (last accessed 14 December 2020). 
the face that claims the right to its own impertinence, no longer respecting the original system of proportions envisaged by the frame of the shot, and therefore going out of view or changing its relationships with the depth of field and moving towards the fore. ${ }^{28}$

This last consideration highlights a politics of enunciation to which the face is usually subjected, depending on the format that regulates it (selfie, class photo, passport photo, mirror, home film and so on), and that pushes us to consider it a device that should not be read exclusively within its own borders, but also in a conscious relationship with the environment that contains it, both in the semiotic space of representation, and in that of everyday experience. Experiments such as those reported above, starting from the controversial unhinging of the taboos linked to sexuality and the specifics of orgasm as a moment of escape from a strictly linguistic order of things (although, but this is the game of semiotic analysis, "trapped in the linguistic cage of the text"), reveal how the investigation in this specific direction can actually produce pertinent results for a more general cultural semiotics of the face, whose media relevance appears, in conclusion, to be exquisitely contemporary. It is in fact the liquid society of digital media that allows the development of a pragmatics of the represented face that can move easily. In the past, the orgasmic face was simply relegated not even to the margins, but in the dark area of the unculture, that is, the unspeakable and the unrepresentable. Today, however, in an era in which nudity is ordinary, pornography socially metabolized, and sexuality no longer the subject of discussion as such but rather a symbol of battles for the achievement of rights, the face takes on its own public role as a privileged support for proposing a shared semiotics of reappropriation, of redemption of impertinence.

Thus, on the interpretative level, there are two ways of reading the video $O$ Face presented by DirtyFit Apparel. ${ }^{29}$ On the one hand, it will certainly be agreed that this is an advertising operation, conceived by the brand to involve the audience and somehow secure a place within a specific imaginary, built around the enhancement of certain libertarian, if not even socially anarchoid, values. On the other hand, however, it will be inevitable to conclude that the sequence of faces of people of every gender, ethnicity and age, captured in the foreground, sometimes with emphasis on details (the trembling mouth, the widening nostrils and so on) during their moment of ecstasy, constitutes the symptom and at the same time the result of a strong cultural renegotiation, which passes through the face, of the elastic

28 The work can be viewed at the following link: https://www.marcosalberti.com/oproject (last accessed on 14 December 2020).

29 The video can be viewed at the following link: https://www.youtube.com/watch?v= mISaDN65eX8\&has_verified $=1$ (last accessed on 14 December 2020). 
distinction between private and public, between intimate and exhibitable, between unbecoming and licit. In a semio-politics of bodies, the face obviously plays an indispensable and definitive role.

Acknowledgements: This article is part of FACETS - Face Aesthetics in Contemporary E-Technological Societies, a project funded by the ERC (European Research Council) under the Horizon 2020 programme (Grant agreement 819649).

\section{References}

Barthes, Roland 1973. Le plaisir du texte. Paris: Seuil.

Broekman, Jan 2011. Faces face to face. In: Broekman, Jan M.; Mootz III, Francis J. (eds.), The Semiotics of Law in Legal Education. London, New York: Springer, 21-56. https:// doi.org/10.1007/978-94-007-1341-3_2

Chen, Chaona; Crivelli, Carlos; Garrod, Oliver; Schyns, Philippe; Fernández-Dols, JoséMiguel; Jack, Rachael 2018. Distinct facial expressions represent pain and pleasure across cultures. PNAS - Proceedings of the National Academy of Sciences of the United States of America 115(43): E10013-E10021. https://doi.org/10.1073/pnas.1807862115

D’Aloia, Adriano; Eugeni, Ruggero 2017. Teorie del cinema. Il dibattito contemporaneo. Milano: Raffaello Cortina.

Da Silva, Odair José Moreira 2013. A significação e o sentido do corpo orgástico no cinema pornô. Signum: Estudos de Linguagem 16(1): 149-170. https://doi.org/10.5433/22374876.2013v16n1p149

Eco, Umberto 1975. Trattato di semiotica generale. Milano: Bompiani.

Fernández-Dols, José-Miguel; Carrera, Pilar; Crivelli, Carlos 2011. Facial behavior while experiencing sexual excitement. Journal of Nonverbal Behavior 35(1): 63-71. https:// doi.org/10.1007/s10919-010-0097-7

Fontanille, Jacques 2004. Soma \& séma: figures $d u$ corps. Paris: Maisonneuve \& Larose.

Gallese, Vittorio; Guerra, Michele 2015. Lo schermo empatico. Cinema e neuroscienze. Milano: Raffaello Cortina.

Grundmann, Roy 2003. Andy Warhol's Blow Job. Philadelphia: Temple University Press.

Kaite, Berkeley 1995. Pornography and Difference. Bloomington, Indianapolis: Indiana University Press.

Leone, Massimo 2018. I giga di Gige. L'impatto dell'anonimato nella comunicazione contemporanea. RIFL/SFL - Rivista italiana di filosofia del linguaggio 1: 101-109.

Leone, Massimo 2019. On Insignificance: The Loss of Meaning in the Post-Material Age. London, New York: Routledge. https://doi.org/10.4324/9780429461279

Leone, Massimo; De Riedmatten, Henri; Stochita, Victor (eds.) 2016. Il Sistema del velo. Trasparenze e opacità nell'arte moderna e contemporanea. Roma: Aracne.

Lévinas, Emmanuel 1984. Paix et proximitè. Cahiers de la nuit surveillé 3: 339-346.

Lloyd, Elisabeth A. 2005. The Case of the Female Orgasm: Bias in the Science of Evolution. Cambridge, London: Harvard University Press. 
Longhurst, Brian; Smith, Greg; Bagnall, Gaynor; Crawford, Garry; Ogborn, Miles 2017. Introducing Cultural Studies. London, New York: Routledge. https://doi.org/10.4324/ 9781315690070

Lykousas, Nikolaos; Casino, Fran; Patsakis, Constantinos 2020. Inside the X-rated world of "premium” social media accounts. In: Samin, Aref; Bontcheva, Kalina; Bragieri, Marko; Dignum, Frank; Jannotti, Foska; Grisolia, Franchesko; Pedreschi, Dino (eds.), Social Informatics. 12th International Conference, Pisa, Italy, October 6-9, 2020. Proceedings. Cham: Springer, 181-191. https://doi.org/10.1007/978-3-030-60975-7_14

MacCannell, Dean 1989. Fakin it: Comment on face-work in pornography. American Journal of Semiotics 6(4): 153-174. https://doi.org/10.5840/ajs19896410

Makolkin, Anna 2015. Face as a sign and Paolo Mantegazza's theory of metoposcopy. In: Trifonas, Peter Pericles (ed.), International Handbook of Semiotics. London, New York: Springer, 573-588. https://doi.org/10.1007/978-94-017-9404-6_26

Mann, Steve 1998. Reflectionism and diffusionism. Leonardo 31(2): 93-102. https://doi. org/10.2307/1576511

Mann, Steve 2004. "Sousveillance": Inverse surveillance in multimedia imaging. MULTIMEDIA '04: Proceedings of the 12th annual ACM international conference on Multimedia, 620-627. https://doi.org/10.1145/1027527.1027673

McCosker, Anthony; Wilken, Rowan 2020. Automating Vision: The Social Impact of the New Camera Consciuosness. London, New York: Routledge. https://doi.org/10.4324/ 9780429341175

Ortoleva, Peppino 2009. Il secolo dei media. Riti, abitudini, mitologie. Milano: Il Saggiatore.

Paasonen, Susanna 2007. Strange bedfellows: Pornography, affect and feminist reading. Feminist Theory 8(1): 43-57. https://doi.org/10.1177/1464700107074195

Ponzio, Augusto 2007. Fuori Luogo. L'esorbitante nella riproduzione dell'identico. Roma: Meltemi.

Salecl, Renata; Žižek, Slavoj (eds.) 1996. Gaze and Voice as Love Objects. Durham, London: Duke University Press. https://doi.org/10.2307/j.ctv11smjs5

Saussure, Ferdinand de. 1916. Cours de linguistique générale. Lausanne, Paris: Payot.

Schaschek, Sarah 2014. Pornography and Seriality: The Culture of Producing Pleasure. New York: Palgrave MacMillan. https://doi.org/10.1057/9781137359384

Surace, Bruno 2018. Sintassi, semantica e pragmatica del martirio attorno a Martyrs di Pascal Laugier. Lexia 31/32: 351-367.

Surace, Bruno 2019. The unbridled meaning of unsignified signifiers from paraliterature to cinema. In: Idone Cassone, Vincenzo; Ponzo, Jenny; Thibault, Mattia (eds.), Languagescapes: Ancient and Artificial Languages in Today's Culture. Roma: Aracne, 131-143.

Surace, Bruno 2019. Where porndom meets stardom. In: Jacob, Frank (ed.), Pornography: Interdisciplinary Perspectives. Berlin: Peter Lang, 239-260.

Thibault, Mattia 2016. Untag yourself. Opacità e trasparenze negli stili di vita online. Carte semiotiche 4: 103-118.

Voros, Florian 2014. Gendered embodiment in audience reception practices of pornography. In: Biasin, Enrico; Maina, Giovanna; Zecca, Federico (eds.), Porn after Porn: Contemporary Alternative Pornographies. Milano, Udine: Mimesis.

Yelle, Robert 2013. Semiotics of Religion: Signs of the Sacred in History. London, New York: Bloomsbury. 
Ziplow, Steven 1977. The Film Maker's Guide to Pornography. New York: Drake Publishing. Žižek, Slavoj 2004a. Organs Without Bodies: Deleuze and Consequences. New York, London: Routledge.

Žižek, Slavoj 2004b. Dello sguardo e altri oggetti: saggi su cinema e psicoanalisi. Pasian di Prato: Campanotto.

\section{Семиотика порнографического лица: от традиционного порно до Прекрасной Агонии}

Современная порнография представляет собой семиотическую лабораторию, способную скрупулезно описывать некоторые характеристики культур, в которых она создается и для которых предназначена. Лицо играет здесь главенствующую роль и приобретает особое значение как с диегетической, так и с формальной точки зрения. Лицо, становящее знаком и артикулируемое в диалектике между синтагматической и парадигматической осью, находит выражение в качестве аспектуального приема, устанавливает своеобразную семиотическую процедуру “absentia in praesentia” и подчеркивает крайне выразительное измерение текстового жанра. Таким образом, в порнографии семиотика лица становится семиотикой культуры во всех смыслах, которая благодаря исследованию этого трансверсального жанра - как в его основном, так и в более нишевых актуализациях - дает значительные результаты в определении того, как культуры лица, включая непорнографические, себя определяют. Цель этой статьи - проверить эту гипотезу, прослеживая историю вопроса от традиционной до современной порнографии, а также анализируя веб-сайт «порнографии лица» beautifulagony.com и работы некоторых современных художников.

\section{Pornograafilise näo semiootika: traditsioonilisest pornost Kauni Agooniani}

Tänapäeva pornograafia moodustab semiootilise laboratooriumi, mis võimaldab üksikasjaliselt kirjeldada mõningaid iseloomulikke jooni kultuuris, millest see on pärit ja mille jaoks mõeldud. Näole kuulub selles väljapaistev roll ning see osutub oluliseks nii diegeetilisest kui ka vormilisest vaatepunktist nähtuna. Nägu, mis muudab end märgiks ning mida väljendatakse süntagmaatilise ja paradigmaatilise telje dialektikas, leiab väljenduse aspektuaalse võttena, mis kehtestab “absentia in praesentia" omapärase semiootilise protseduuri ning rõhutab teksti žanri ülimalt enuntsiatiivset mõõdet. Seega saab pornograafias näosemiootikast igas mõttes kultuurisemiootika, mis mitut valda ületava žanri uurimisel annab olulisi tulemusi defineerimaks, kuidas näokultuurid, sealhulgas ka pornograafiavälised, end määratlevad. Artikli eesmärgiks on kinnitada seda omapärast näosemiootikat juhtumiajaloo abil, mis ulatub traditsioonilisest kuni kaasaegse pornograafiani, analüüsides ka "näoporno" veebilehte beautifulagony.com ning mõnede kaasaegsete kunstnike visuaalset loomingut. 